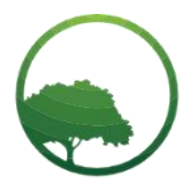

Research in Business \& Social Science

IJRBS VOL 10 NO 6 ISSN: 2147-4478

\title{
Public interaction of health workers during the Covid-19 pandemic
}

\author{
Dara Anglelorenza Pricilly Dea ${ }^{(a) *(1)}$ Maharani Aliefya Rachim ${ }^{(b)}$ \\ Crossref \\ ${ }^{(a, b)}$ Program Pascasarjana Ilmu Komunikasi, Institut Komunikasi dan Bisnis LSPR, Sudirman Park, Sudirman Park JL. KH Mas Mansyur Kav.35, \\ Jakarta, Indonesia
}

\author{
ARTICLE INFO \\ Article history: \\ Received 21 August 2021 \\ Received in rev. form 18 Sep. 2021 \\ Accepted 22 Sept 2021 \\ Keywords: \\ Coordinated Management of \\ Meaning, Health Communication, The \\ role of health workers \\ JEL Classification: \\ O15; P36
}

\begin{abstract}
A B S T R A C T
The impact of the COVID-19 pandemic has limited the space for the community and health workers to provide health services. In this study, we want to see how the role of health workers can minimize health problems that occur in the field. GERMAS (Gerakan Masyarakat Hidup Sehat) which contains to implement the health service programs seeks to provide information through mobile broadcasts on services for preventing Covid-19 activities through vaccination and distributes anthelmintics to children, which is expected to be a forum for the health service to keep interacting with children and societies and also to give some meanings or messages to conveyed the community. This research used a qualitative descriptive method with case study methods and data collection techniques through interviews and observations. The theory used in this research is Coordinated Management of Meaning. For the results, Tanjung Selor Health Center Health Workers and the Tanjung Selor community set a pattern to create a meaning in their communication. Health workers and communities create meaning and interpret meaning in their activities through the GERMAS Program.
\end{abstract}

() 2021 by the authors. Licensee SSBFNET, Istanbul, Turkey. This article is an open access article distributed under the terms and conditions of the Creative Commons Attribution (CC BY) license (http://creativecommons.org/licenses/by/4.0/).

\section{Introduction}

Health is the main factor that must be continuously pursued and considered for the sake of a prosperous society. Personal health is the primary support to be able to carry out daily activities. However, until now, the public health rate is still low enough to be a government concern. Indonesia is ranked 4th in the Southeast Asia Global Health Resilience Index. This is what the Indonesian government is still paying attention to, where diseases have put Indonesia in 4th position after Singapore (Hopkins Center for Health Security, 2019). To overcome this, health control is needed. This is done by the community and in collaboration with health workers to make it easier for the public to understand how to pay attention to and care for health correctly and adequately. Many things are a challenge to continue to focus on improving health rates. In 2020, Indonesia was hit by the Covid-19 pandemic, which made health campaign activities even more stringent to avoid being attacked by the Covid-19 virus and improve people's welfare $\&$ productivity. As of June 16, 2021, Covid-19 cases in Indonesia have reached around 1.93 million patients with a total recovery of 1.76 million people and 53,280 deaths, while the Covid-19 virus case in North Kalimantan, precisely in Tanjung City, has the total number of confirmed cases reached 3,104 people (PUSKESMAS Tanjung Selor, North Kalimantan, 2021).

This causes people's welfare for health services to decline, which results in unstable health rates (National Geographic, 2020). The Covid-19 pandemic is the biggest challenge for health workers today, who must focus on dealing with Covid-19 patients with health services in general. Even prevention programs such as screening (breast and cervical cancer) are disrupted in more than 50\% of countries. At this time, the Community Health Center or commonly known as the PUSKESMAS, put more effort into Preventive and Promotive efforts as a prevention of the scope of public health as well as the actions of health workers in carrying out health promotion and campaigning more for various kinds of diseases that are often found in the field. In the Tanjung Selor city area, there was a decline in public health numbers before the Covid-19 pandemic and during the Covid-19 pandemic (See appendix.)

* Corresponding author. ORCID ID: 0000-0002-2297-1778

(C) 2021 by the authors. Hosting by SSBFNET. Peer review under responsibility of Center for Strategic Studies in Business and Finance. https://doi.org/10.20525/ijrbs.v10i6.1366 
In PUSKESMAS, activities such as posyandu (Pos Pelayanan Keluarga Berencana), routine socialization to the community, immunization, and other health services eventually decreased. This is due to the public's fear of the dangers of this virus. People are worried about being exposed to the Covid-19 virus if they visit the PUSKESMAS to get health services. Therefore, the Healthy Living Community Movement program, commonly called GERMAS through mobile broadcast services, has become an activity in preventive and promotive efforts to reduce the number of health problems in the field. The mobile broadcasting activity is a subsidiary program from GERMAS, which was intensely carried out during the Covid-19 pandemic. Health workers carry out mobile broadcast activities to carry out health promotions and convey information about various health problems in the field. In this case, GERMAS aims to prevent preventable diseases from maintaining the quality of people's lives. GERMAS is a systematic and planned movement carried out by all components of the nation together with full awareness, willingness, and ability to behave healthily.

This study aims to analyze the construction study of the meaning of the relationship between Health Officers at the Tanjung Selor Health Center and the Tanjung Selor community with a model approach (Coordinated Management of Meaning-CMM). Coordinated Management of Meaning is a theory that asserts that communication is a process by which people make sense of their world and generate social realities. This theory was first developed by Barnett Pearce and Vernon Cronen in the late 1980s. They argue that communication is central to being human, and people create their everyday reality. Creating meaning in interactions is achieved by applying various rules based on the content of the communication, stated actions, situations, relationships between communicators, individual backgrounds, and cultural patterns (West and Turner, 2009). The CMM theory is used in this study because it explains how GERMAS socializes health to the surrounding community. Therefore, the interaction of health workers plays a role in conveying information about public health in the GERMAS program on mobile broadcasting services. The new challenges facing the Covid-19 pandemic require health workers to build a good relationship by using an approach to create good communication between health workers and the community so that the program's objectives are implemented. In this case, the health cases that occur in the field become a reference to attract the public's attention to want to follow the health regulations that have been enacted.

Individuals will carry out accommodation to adapt when they are communicating with other individuals. In this case, every communication process between Health Officers at the PUSKESMAS and the community in Tanjung Selor has a purpose, including when conducting health communication. Accommodation made by Health Officers when communicating to fulfill various purposes refers to positive things to be achieved or something that Health Workers want to maintain. In the accommodation process, humans tend to have internal cognitive assumptions or by their understanding and experience of what someone knows about others as a guide that we use when we talk to others. Tanjung Selor Health Officers have experience in communicating with the community. With this experience, it becomes a guideline for Health Workers in a step taken to support the dissemination of health information from the GERMAS program that is being carried out.

Furthermore, the role of Health Workers in building communication with the community is the most important thing to achieve the level of coordination. Likewise, mobile broadcasting activities can carry out promotive and preventive activities during the COVID19 pandemic as prevention activities and promote health services carried out by Health Officers to achieve a level of coordination in a message conveyed through conversations that are carried out so that the people of Tanjung Selor can better understand and be able to implement the programs that have been planned quickly and accurately. From this explanation, the authors are interested in researching the efforts of Tanjung Selor Health Officers in disseminating GERMAS and describing the community's response by using the Coordinated Management Of Meaning (CMM) theory.

\section{Literature Review}

\section{Health Communication}

Health communication is part of human-to-human communication that focuses on how individuals in a group/community face healthrelated issues and seek to maintain their health (Northouse in Notoatmodjo, 2005). The main focus in health communication is the occurrence of transactions specifically related to health issues and the factors that influence these transactions. Transactions between health professionals, between health professionals and patients, and between patients and their families are a significant concern in health communication. Health communication is a systematic effort to positively influence the health behavior of individuals and communities, using various principles and methods of communication, both interpersonal communication and mass communication. In addition, health communication is also understood as a study that studies how to use communication strategies to disseminate health information that can influence individuals and communities to make the right decisions related to health management (Liliweri, 2008).

Health communication includes information about disease prevention, health promotion, health care policies, business regulations in the health sector which as far as possible change and update the quality of individuals in a community by considering scientific and ethical aspects. Thus, it can be understood that health communication is the application of communication concepts and theories in transactions between individuals or groups on health issues. The primary purpose of health communication is to change health behavior to improve health status. Health communication can increase public awareness about health issues and solutions. Increasing individual awareness of matters related to health will also impact the individual's family and environment. For example, if in a family there is a family member who has diabetes, as a patient, he must pay close attention to his daily food intake. His diet must be 
maintained automatically and adequately. Other family members must also understand the appropriate diet arrangements. The environment in which he is sick will adjust, and each individual will better understand and despise the disease.

Individual behavior is certainly very influential on the quality of his health and even those around him. The individual is in a biological, psychological, and social situation. These three factors affect the health status of an individual. Through this, health communication can learn the reciprocity between the three factors. This understanding is essential so that health program interventions can be developed that aim to change individual behavior to become healthier in the future. The recent trend is that social factors and behavioral influences cause most chronic diseases. Many chronic diseases are caused by an individual's inability to lead a healthy life and failure to maintain health. The most obvious example is cancer, where the trigger is smoking, even though they know the impact of the cigarette. So, if you are aware of the dangers of smoking, why is this behavior still being carried out? It turns out that cigarettes can give him peace and comfort due to the content in the cigarette. But still, this is very detrimental to the health of his own body. We can see that someone who was not a smoker will become a smoker in a smoker's social environment. With the influence of biology, psychology, and society, it is necessary to have healthy communication media about the negative impact of smoking on smokers so that this unhealthy habit does not continue, likewise with various other diseases. One of them is Covid-19 which is a pandemic at this time.

\section{Coordinated Management of Meaning}

Coordinated Management of Meaning is a theory that asserts that communication is a process by which people make sense of their world and generate social realities. This theory is a comprehensive approach to social interaction that employs complex procedures of action and congruent meaning in communication (Littlejohn \& Foss 2009). This theory was first developed by Barnett Pearce and Vernon Cronen in the late 1980s. They argue that communication is central to being human, and people create their everyday reality. Creating meaning in interactions is achieved by applying various rules based on the content of the communication, the actions expressed, the situation, the relationship between the communicators, the background of the individual, and cultural patterns.

Coordinated Management of Meaning (CMM) theory was created by Barnett Pearce (The Fielding Graduate Institute) and Vernon Cronen (University of Massachusetts). The rationale that leads one to this theory is the belief that "the quality of our personal lives and the quality of our social world are directly related to the quality of communication in which we engage. Because conversation (in general communication) between humans is the essential ingredient that forms the social world (social universe). Therefore, (the CMM theory also begins by saying), humans in conversations (persons-in-conversation) co-construct social reality (social reality) and are simultaneously shaped by the social world they create themselves. Pearce and Cronen made CMM theory a practical theory that can help people to achieve a better life. By having good conversations, people can improve the quality of their personal life and the quality of their social world (Littlejohn \& Foss, 2009).

Indeed, it can be concluded that CMM is a theory that helps someone understand more deeply how individuals who create meaning in communication conversations must be understood and done correctly to provide the best benefits. Overcoming a communication problem is always the best middle ground where every group can resolve the issue. Likewise, what is happening now, the Covid-19 pandemic, which is becoming a severe problem for many people in Indonesia and even internationally, requires stable and good communication skills by health workers who are indeed experts in this field in overcoming problems that occur in society. Value and develop quality. In CMM theory, there are three levels of meaning of CMM theory, namely:

i. Meaning \& Action, namely understanding the process of meaning and action that informs every communication event and how one coordinates activities with others in the interaction process. Purpose leads to move, and movement forms essence. Communicators must coordinate their meanings and actions when interacting. Overall, social interaction must regulate the interaction process while also responding to the purpose and actions of other people. It is a story lived and done (Littlejohn \& Foss 2009).

ii. Coordination, which is a coordinated activity where both parties are satisfied. People can have good coordination without having the same meaning (Littlejohn \& Foss 2009). Communicators achieve coordination when interactions feel appropriate and logical. Sometimes parties don't understand interactions in the same way. This does not necessarily become a problem as long as partners can work together smoothly. (Littlejohn \& Foss, 2009). The second key concept in CMM, coordination, is the effort to match one person's actions with the actions of others at the level or level where the various steps taken are felt to be logical and appropriate. Communicators organize their meanings and activities into coordination and continue to maintain that coordination among the parties involved. (Morissan, 2013). When one person acts, then the other person must interpret the action. Then the second person will affect or respond based on that meaning. But at the same time, coordination is not always good. An unwanted repetitive action is a highly uncoordinated action that no one wants. (Pearce, W. B. (2008).

iii. Stories are a tool to help communicators understand the situation. When two communicators share stories about what happened, it creates a kind of mutual coherence or understanding that usually leads to a high degree of coordination. It is also possible for communicators to remain perfectly coordinated by understanding each other (Littlejohn, Foss, \& Oetzel, 2017). Then stories, providing a way to frame experiences, are a means to achieve coherence in situations. We create context, establish meaning, and define action through stories. (Littlejohn \& Foss, 2009). 


\section{Research and Methodology}

The approach used in this research is a descriptive qualitative approach. The type of qualitative research method used is a case study. The use of this method is based on the consideration of the case to be studied, that the patient requires direct observation in the field, and obtaining a close emotional relationship with the informant to produce clear data. This research will focus on health workers conducting GERMAS counseling activities to increase public awareness amid the Covid-19 pandemic. The informants who will be interviewed are health workers from the Tanjung Selor Health Center and the community who participate in GERMAS activities. The people who become informants are government employees who have a background of knowledge or have participated in the GERMAS program and informants of Health Workers who are in charge of the program implemented by GERMAS at the Tanjung Selor Health Center. The criteria determined by the researchers in this study are (1) the community, who are people involved in the GERMAS program, who know or have participated in the GERMAS program, (2) Health Workers, are the people in charge of the GERMAS program at the Tanjung Health Center. Selor. The following is the data of the informants in this study:

Table 1: List of Informant

\begin{tabular}{lll}
\hline $\mathbf{N o}$ & Informant & Role \\
\hline $\mathbf{1}$ & Muhrida S S,S.Kep.,Ns & Penanggung Jawab Upaya Kesehatan Masyarakat (Health workers) \\
\hline $\mathbf{2}$ & Sri Astuti Momba, SKM & Koordinator Suverilans PUSKESMAS Tanjung Selor (Health workers) \\
\hline $\mathbf{3}$ & Christya C. V. W, A. Md. Kep & Penanggung Jawab Pembagian Obat Kecacingan (Health workers) \\
\hline $\mathbf{4}$ & Muhammad Rudyanto & Citizen \\
\hline $\mathbf{5}$ & Johan & Citizen \\
\hline $\mathbf{6}$ & Virda Clarita & Citizen \\
\hline $\mathbf{7}$ & Susilawati & Citizen \\
\hline
\end{tabular}

In this study, the data analysis process was carried out continuously from the beginning of the study to the end of the study, both before and after research in the field using the data analysis method by Yin (2013) :

Relying on theoretical propositions:

One of the strategies includes theoretical propositions that lead to the case studies under study. This case study's original aims and design reflect a series of research questions and a review of the literature. The propositions will shape the data collection plan and, therefore, will generate analytical priorities. Offers help to organize the whole analysis, pointing to relevant contextual conditions to explain and explanations to examine.

Working your data from the ground up:

A second strategy is in direct conflict with the first. Instead, think about propositional theory pouring through existing data. This inductive strategy can produce benefits that can be demonstrated again in research theory. In the case of studies, the inductive approach offers an adjunct if the case study understudy calls for the collection of quantitative data, which for two reasons may be relevant. First, the data may include the behaviors and events that "outcomes" are trying to explain in an evaluative case study. Second, the data may relate to the unit of analysis embedded in the broader case study.

Developing case descriptions :

The third general analytic strategy is to organize case studies according to several descriptive frameworks. This strategy can serve as another option if the research has difficulty using the first two strategies. In other words, research has collected a lot of data without solving the initial set of research questions or propositions (paralyzing the research ability to rely on the first strategy), and the research may also not be able to emerge valuable concepts from the existing data (making it difficult to follow the second strategy or inductive approach).

\section{Examing rival explanations:}

The fourth general analytic strategy, trying to define and test plausible explanations, generally combines the three previous methods. Your case study data collection should include efforts to gather evidence about relevant "other influences." In addition, research can pursue research data collection with gusto as if the research is trying to prove other potential influences rather than finding reasons to reject it (Patton, 2015).

In this data analysis, it will also be seen how the program can run so as to produce something that is expected by an activity that has been carried out. 


\section{Result and Discussion}

In conducting the socialization of the GERMAS program (Healthy Living Community Movement) conducted by Health Officers at the Tanjung Selor Health Center, it can be seen that the socialization of the GERMAS program with the Coordinated Management Of Meaning Theory. Interviews were conducted with the medical personnel of the Tanjung Selor Health Center, and the residents of Tanjung Selor City, the analysis carried out in this study combined the explanations given by the informants, namely Rida's mother, Sri Astuti's mother. In addition, the reasons that have been given will also be supported by statements issued by residents of Tanjung Selor City, who are the target targets in delivering information through outreach activities. Tanjung Selor residents can also provide an idea of whether the socialization that has been carried out has been appropriately conveyed or not. Coordinated Management of Meaning generally refers to how individuals define the rules for creating and interpreting the meaning and how these rules are interwoven in a conversation where meaning is always coordinated.

Rules play an essential role in communication in social interactions; controls help individuals communicate and interpret what is displayed in social interactions. Health workers at the Tanjung Selor Health Center and the Tanjung Selor community set a pattern in determining interactions with their environmental conditions that help build meaning in their communication. Health workers and communities create sense and interpret meaning in their activities. This is related to the assumptions contained in the Coordinated Management of Meaning theory.

\section{Meaning and Action}

Meaning and Action, namely understanding the process of meaning and Action that informs every communication event and how a person coordinates actions with others in interaction. Meaning leads to Action, and Action forms meaning. Communicators must coordinate their meanings and actions when interacting. Overall, social interaction must regulate the interaction process while also responding to the meaning and actions of other people. It is a story lived and done (Littlejohn \& Foss 2009). Communication is a process of Action and reaction, human interaction that takes place on an ongoing basis. For this reason, someone who conveys a specific message only needs another party as the recipient of the message. Therefore, in the communication process, at least get, and the person who receives the feelings of a person or group of people can be understood by the other party.

The first assumption of the Coordinated Management of Meaning theory is the importance of communication. That is, humans live in contact. Social situations are created through interaction because individuals generate the reality of their conversations. Health Workers create new realities for themselves, and these realities will be based on verbal and nonverbal communication in people's lives. Discussions will often be defined by what both parties know and don't know. These two parties will depart from two different conversational rules, and therefore will reach different conclusions when discussing a problem.

Regarding the findings, the author found that communication with the Tanjung Selor Health Center medical personnel successfully conveyed the objectives of the GERMAS program through mobile broadcasts. However, the public does not know about the name of the GERMAS Program. This can be seen from the reaction of Tanjung Selor when asked about the GERMAS program in mobile broadcasting services. Ibu Susilawati (Informant from the Community) emphasized that they did not fully understand the name of the activity.

In this case, the public can get information from the GERMAS Program in health services and mobile broadcasts. There is a public response when they see mobile broadcasts and hear about the provision of health information so that it raises the public's willingness to interact directly with health workers as is the case with Mr. Ardyanto (Informant from the Community), who has received previous information and implemented it for children in giving worm medicine. Communication will only be effective if the message conveyed can be interpreted the same by the message recipient. There is a process of equating the meaning of one with another. Likewise, with the communication process between Health Workers and the Community, the GERMAS program will be understood by the community by equating perceptions by both parties. The program from GERMAS conducted by Health Workers is socialized with various activities, one of which is mobile broadcasts. This activity is carried out by traveling around the city of Tanjung Selor by car and loudspeaker.

The message conveyed in this mobile broadcast activity was the distribution program for deworming medicine and socialization and vaccination for COVID-19. Medical personnel around the city with loudspeakers visit the neighborhood. If there is a crowd in an area, usually Health Workers also come to provide socialization. According to Liliweri (2008), Health communication is also understood as a study that studies how to use communication strategies to disseminate health information that can influence individuals and communities to make the right decisions related to health management. Tanjung Selor Health Workers conduct mobile broadcasts to communicate the GERMAS program to community groups regarding several programs carried out by GERMAS. The author only focused on the distribution program for deworming drugs and the Covid-19 vaccination in this study. Health communication carried out by Tanjung Selor Health Officers is carried out to carry out promotional and preventive efforts. By doing a mobile broadcast to the community, it is hoped that the community can implement that health is an important thing that must be maintained. An effective interpersonal communication relationship occurs when two or more interacting individuals reach an understanding or perception of the same thing. In the end, the communication will happen in a pleasant atmosphere and based on this. Interpersonal communication will be achieved. Communication will be effective if it uses the right approach so that it helps individuals to attain effective communication (Putri and Sawitri, 2018). 
The community's response to this activity was responded positively. This can be seen from the community's enthusiasm by visiting the Health Personnel on duty at that time. Society seeks what information is conveyed and consults with the Medical Personnel on duty. Although initially, the community did not respond to the mobile broadcasting activities. The explanation by Mrs. Virda (Informant from Health Workers) illustrates the public's reaction to interactions with health workers on mobile broadcasts. This is because the community was still active at the time of the activity, so they were not too focused on listening to what was being said. However, health workers approach the community by visiting residents, such as giving worm medicine and voicing the message they want to convey. So the public better understands the message to be brought in the mobile broadcasting activity. The approach taken by the Tanjung Selor Health Officer is a socialization activity. The message conveyed by Health Workers to the community must be attractive so that people want to interact with Health Workers. Therefore it will achieve the goal of the desired socialization.

With the socialization, it is expected that the delivery, implementation, and messages addressed to the targeted or targeted community will proceed according to the previously regulated plan. Everyone has their interpretation and finds their meaning when interacting with other people. Constructing meaning during a conversation consists of interpersonal systems that explain actions and reactions.

Rules in CMM theory explain meaning and action based on rules. Rules are guidelines that help people define meaning and take action (Littlejohn \& Foss 2009). Rules are guidelines that help a person establish meaning and take action. Rules in meaning can respond to actions made by individuals and understand an event or message (Littlejohn, Foss, Oetzel 2017). Once upon a time, there was a boundary between constitutive and regulative rules as long as they were used in the conversion process. If there was a dispute, unwanted repetitive patterns would arise, or repeated and unwanted conflicts in a relationship. (Littlejohn \& Foss, 2009). In this case, constructive rules are rules used by communicators in providing an interpretation or giving understanding in an event or message. Here, the performance of the message can help to understand the meaning of the message. Health workers explain how the process, use, and prevention. With this interpretation, it can be concluded that the public will get the information they need.

Regulatory rules regarding actions or reactions in responding or behaving when receiving a message. Authorities see how individuals react to news and respond to messages received (Littlejohn, Foss, Oetzel 2017). In the GERMAS program, Health Workers provide information about the program that will be carried out before conducting a mobile broadcast, namely providing initial information via Whatsapp. The people of Tanjung Selor received initial data regarding the distribution of worm medicine and vaccines through the issuance of Whatsapp information. With the data obtained, the reaction of Tanjung Selor with the existence of this mobile broadcasting activity indirectly responded to the message previously conveyed. The response taken by the people of Tanjung Selor was to go to health workers who were on duty on mobile broadcasting activities by asking about information both about vaccines and distribution of deworming drugs for children.

Furthermore, after conducting a mobile broadcast, Tanjung Selor health officers distributed deworming drugs and vaccines. This activity is carried out by following the stages from registration to administering drugs or vaccines. The distribution of deworming medicine for children is carried out in schools and given to parents. At the time of dispensing deworming, Tanjung Selor's people reacted during the activity by asking questions about how to use deworming medicine for children. This reaction ensures that the people of Tanjung Selor can give deworming treatment to their children according to the time of providing the child deworming medication.

In the mobile broadcast carried out by the Tanjung Selor Health Officer, the reaction that occurred during the activity was a conflict in the conversion process. In this case, the response that caused the competition was that the people of Tanjung Selor were indifferent to the broadcast. With people who do not respond to what has been said by health workers, in this case, health workers try to take a more in-depth approach so that health information and disease prevention are still conveyed, such as the explanation from Mrs. Muhrida (Informant from Health Workers) who is the Person in Charge Public Health Efforts at Tanjung Selor Health Center. These rules guide for people to behave. Once upon a time, there was a boundary between constitutive and regulative rules as long as they were used in the conversion process. If there were a dispute, unwanted repetitive patterns would arise or repeated and unwanted conflicts in a relationship (Littlejohn \& Foss, 2009).

In CMM, the rules of meaning and action are logical forces that emerge in salient contexts. Analytic power is the cognitive relationship between meaning and action. Rules give us a sense of what "logical" (logical) in certain situations is called "logical force." Because humans behave in a manner consistent with their rules, those rules provide the logical power to perform specific actions. Given certain circumstances, particular meanings or actions feel logically correct. According to Morrisan (2013), there are four types of logical styles displayed in CMM: (1) Prefigurative power, the relationship of events that have been experienced previously, and causes a person to feel pressured to behave in specific ways. So that a person feels that his behavior is determined by something that happened before, (2) practical power is also goal-oriented, this power has the achievement of experimental results, (3) contextual power as the goal It has a deterministic tone that is less connected to specific previous actions and more related to meaning in context, (4) implicative power, where the action is designed to change the context or meaning in carrying out a transformation to encourage or change someone to take any action to achieve something.

In communicating with the community, Tanjung Selor Health Officers have experience which will later become a reference action they will take when sharing with the community to change their perspective. This action must be correct and logical, which will later become a meaning. As explained above, four types of logic are displayed, but in the interaction process carried out by Health Officers and the community, they say a fourth logic style, namely Implicative. This can be seen when Health Officers conduct socialization 
during the distribution of deworming drugs to children in schools and when interacting with the community when asking for health history and explaining some of the effects of diseases that can be caused. During the process of communism, there was a refusal from the parents of the students because they had doubts about the drugs given to their children. This was due to the experience of the people of Tanjung Selor regarding the distribution of elephantiasis deworming medicine carried out by the Tanjung Selor Health Center in 2020. There were side effects such as nausea, headache, and low blood pressure after consuming elephantiasis deworming medicine distributed to adults. With this experience, the community is quite anxious about the worm medicine given to their children.

Based on the problems that occurred, the Health Officers immediately responded to the understanding of Tanjung Selor regarding the deworming medicine for children. It will have the same effect as the elephantiasis deworming medication distributed in the previous year. The criticism submitted by the people of Tanjung Selor was responded to with an implicative attitude, namely by providing an understanding that this deworming medicine for children did not have the same side effects as the deworming medicine given previously. This was emphasized by Mrs. Christia Christyowati (Informant from Health Workers who are Health Officers responsible for distribution activities. With the problems that occur in the community, especially regarding the information on the side effects of children's deworming drugs, Tanjung Selor Health Workers as the role of Public Relations must be able to change According to Seitel (2016), another approach to the definition of Public Relations is, "Public Relations is a planned process to be able to influence public opinion through a solid character and appropriate appearance based on mutually beneficial two-way communication.

Furthermore, Mrs. Christia Christyowati explained the importance of giving deworming medicine to children, especially from one year of age to 12 years of age, because providing this deworming medicine to prevent growth disorders or stunting in children. Therefore, the role of health is to inform the public that their children should be regularly given deworming medication. With this explanation, Health Officers communicate when determining meaning and action with implicative logical power, namely adjusting actions according to how to provide feedback instead of giving criticism based on experiences. Like the statement from Mr. Ardyanto (Informant from the Community), who was awakened to consume worm medicine for his child to avoid diseases caused by worms. Health workers, in this case, provide clear information and education to the public regarding the importance of giving children deworming medicine and confirm that there are no side effects such as elephantiasis worm medicine given to adults to provide new understanding to the community.

When meaning and action are consistently carried out in reproducing interactions between individuals, the context of belief in action reinforces a very coherent interaction. When meaning and action are inconsistent and contradict each other, it can affect meaning and action. This occurs when meaning in context shifts, causing changes in the rules of meaning and action (Littlejohn \& Foss, 2009). The activities carried out by the Tanjung Selor Health Center in implementing the GERMAS program are always consistent with the activities held regularly and continuously. Such as the deworming program for children starting at the beginning of the year through mobile broadcasts, which was a promotive effort, then in April 2021, preventive measures were carried out by distributing deworming drugs to children in schools inviting parents. With the socialization of the program for giving children worming medicine, it is hoped that the community can apply it to their social life and the surrounding environment.

Socialization is a process of interaction with people to gain knowledge, attitudes, values, and behaviors essential for effective participation in society (Damsar, 2012). Likewise, with the Covid-19 Vaccine program, the Tanjung Selor Health Center carries out promotional efforts through mobile broadcasts. About the importance of implementing health protocols correctly and adequately. This is carried out routinely and consistently. Even the Tanjung Selor Health Center conducts mobile broadcasting activities two times a day every day. This was done because of the high number of Covid-19 at that time. The mobile broadcast helps the people of Tanjung Selor always to remember to follow the health protocols. This was conveyed by Mrs. Sri Astuti (Informant from Health Workers), the Surveillance Coordinator for the Covid-19 mobile broadcast program and vaccination. A well-planned outreach will make it easier for the public to understand the message conveyed to the public. Then after that, clear messages and proper use of media. Meanwhile, promotive and preventive efforts were also carried out by the Tanjung Selor Health Center in the Covid-19 program, which Health Officers also carried out with various activities. Furthermore, promotive activities are also carried out by involving all elements of society, both government and community leaders. Then, the way that is generally done is to provide sponsorship in a certain way by using local community leaders to highlight the advantages of the programs introduced. With the presence of community leaders, it is hoped that the program carried out by the Tanjung Selor Health Center can run more optimally. Community leaders and several related parties also contribute to changing the culture of the people of Tanjung Selor.

According to LittleJohn (2009), if the context or meaning shifts, it causes changes in the rules of meaning and action. Moreover, the previous culture of Tanjung Selor rarely washed their hands and even used masks before the pandemic came. However, after carrying out promotive efforts with cross-sectoral assistance with approaches to produce new cultural patterns in society. People wash their hands more often and provide handwashing places in their neighborhoods and public areas. Furthermore, with the promotive efforts, the community became aware of the importance of vaccination for Tanjung Selor with people visiting the PUSKESMAS after listening to the information conveyed on the mobile broadcast.

\section{Coordination}

The second key concept in CMM, coordination, is the effort to match one person's actions with the actions of others at the level or level where the various steps taken are felt to be logical and appropriate. Communicators organize their meanings and activities into 
coordination and maintain that coordination among the parties involved (Morissan, 2013). The GERMAS program carried out by the Tanjung Selor Health Center was carried out in promotive and preventive efforts. It was carried out effectively from the distribution program for deworming children and the distribution of the Covid-19 vaccine. Moreover, the services provided by health workers are pretty comfortable, using health protocols, and the education delivered is also quite well felt by one of the residents of Tanjung Selor, namely Mr. Muhammad Ardyanto (Informant from the Community).

On the other hand, Health Officers feel that Tanjung Selor, when providing health services, has a significant impact on the pattern of people's lives. Health officials assess that the change in public awareness is relatively substantial in seeking information during the Covid-19 pandemic. When one person acts, then the other person must interpret the action. Then the second person will affect or respond based on that meaning. But at the same time, coordination is not always good. An unwanted repetitive action is a highly uncoordinated action that no one wants. (Pearce, W. B. (2008).

The GERMAS program carried out by the Tanjung Selor Health Center does not always run smoothly and is bound to experience obstacles. Moreover, when the mobile broadcasting activity was carried out, the public was indifferent to the information conveyed. One of the reasons people still don't care is because they think that complete reports can be obtained through the internet. This situation occurred because there was no coordination between the Health Officers and the Tanjung Selor Community. This is due to the new condition experienced by the people of Tanjung Selor with the Mobile Broadcast. In this case, the information is conveyed when it is essential for the community's health. However, with the efforts made by the Tanjung Selor Health Center with mobile broadcasting activities that are carried out regularly, so that the people of Tanjung Selor understand the message conveyed. Finally, they gave action and reaction by asking about information related to what was said by the Health Workers on duty during the mobile broadcast. Furthermore, Mr. Johan explained that the Health Workers in broadcasting information could be understood well and finally gave a reaction by asking the Health Officers who were at the location.

Communicators achieve coordination when interactions feel appropriate and logical. Sometimes parties don't understand interactions in the same way. This does not necessarily become a problem if partners can work together smoothly (Littlejohn \& Foss, 2009). The coordination between Health Officers and the Tanjung Selor Community is due to understanding in interacting in the same way. The GERMAS program can run optimally for the contribution of all levels of society in the program socialized by the Tanjung Selor Health Center. The coordination built between health workers must be mutually coordinated with one another so that messages can be interpreted through mobile broadcasting activities in a unique way that health workers carry out in the field where this happens when doing mobile broadcasts in crowded areas using music. GERMAS is to attract public attention to health service programs such as prevention of Covid-19 and distribution of deworming medicine to children by saying hello and excuse me for being able to divert people's attention and start asking questions and interacting with health workers. In addition, the coordination built by health workers with the community if they find people on the streets not using health protocols, in this case, health workers approach and provide education and provide PPE such as giving masks.

\section{Stories}

The story is a tool to help communicators understand the situation. When two communicators share stories about what happened, it creates a kind of mutual coherence or understanding that usually leads to a high degree of coordination. It is also possible for communicators to remain perfectly coordinated by understanding each other (Littlejohn, Foss, \& Oetzel, 2017). Since Tanjung Selor implemented the GERMAS program, which Health Workers socialized, they were more concerned with health issues. One of them is the impact of the deworming program for children and the Covid-19 vaccination. The benefits provided by health workers in the GERMAS program are pretty good for the health environment to increase public health awareness to be healthier and calmer in carrying out daily life. As explained by Mrs. Muhrida as the person in charge of Health Services regarding the impact on health problems. According to Endah (2015), health communication is a process of delivering health information to encourage changes in individual and group behavior to improve health status. In addition, with the GERMAS program implemented by the Tanjung Selor Health Center, personal changes occur and occur in the environment around the community. People are more concerned with the surrounding environment, especially starting from the family environment. An experience repackaged in different ways. However, in every interaction, some things cannot be told or known, which complicates the interaction (Littlejohn, Foss \& Oetzel, 2017).

The communication pattern of the Tanjung Selor community can be changed by coordinating with the Tanjung Selor Health Officer. However, there are differences in communication. However, the stories that occurred between the community and Tanjung Selor Health Officers matched so that there was good coordination between the Health Workers and the community. That way, the community can be open to Health Workers. This is proven by Mrs. Virda (Informant from Health Workers), who has openness when checking her health. This pattern was formed because the program implemented by the Tanjung Selor Health Center was running effectively. Promotive and preventive programs are carried out regularly. For the people of Tanjung Selor, the program implemented impacts the pattern of community life. Then stories provide a way to frame experiences; stories are a means to achieve coherence in situations. We create context, establish meaning, and define action through stories. (Littlejohn \& Foss, 2009).

Based on the current findings, six elements serve as the basis for the analysis of the results of this study, which are described in the table as follows: 
Table 2: Summary of Findings

\begin{tabular}{lll}
\hline Element & Evidence & Research Findings \\
\hline Meaning dan Action & $\begin{array}{l}\text { Understand the processes of meaning and actions } \\
\text { that are managed or coordinated in conversation }\end{array}$ & $\begin{array}{l}\text { The people of Tanjung Selor can understand and implement } \\
\text { the GERMAS program that is being run. Judging from the } \\
\text { How conversation produces good meaning in } \\
\text { coordinating actions with other people in the } \\
\text { process of interaction }\end{array}$ \\
& $\begin{array}{l}\text { public can understand directly when interacting with health } \\
\text { workers. } \\
\text { Tanjung Selor Health Officers run Mobile Broadcasts as } \\
\text { socialization to continue to be able to directly communicate } \\
\text { messages conveyed to the Tanjung Selor Community during } \\
\text { the Covid-19 pandemic. }\end{array}$
\end{tabular}

$\begin{array}{ll}\text { Rules } & \begin{array}{l}\text { Constitutive rules: see the conventions used in } \\ \text { providing an interpretation of an event. }\end{array} \\ \begin{array}{ll}\text { Regulatory rules: action or reaction in responding interpretation of Tanjung Selor Health Workers, the } \\ \text { when receiving a message }\end{array} & \begin{array}{l}\text { community can provide understanding through the meaning } \\ \text { and messages to be conveyed by interacting with the } \\ \text { community in the GERMAS Program in mobile } \\ \text { broadcasting services. } \\ \text { There is an approach taken by health workers built against } \\ \text { relevant cross-sector and the community when they get a } \\ \text { negative response during the implementation of the } \\ \text { GERMAS program by Health Officers. }\end{array}\end{array}$

\begin{tabular}{|c|c|c|}
\hline Logical Force & $\begin{array}{l}\text { Implicative power: Seeing how a meaning in a } \\
\text { message can change a pre-existing context. }\end{array}$ & $\begin{array}{l}\text { In the information presented at the GERMAS service by } \\
\text { Tanjung Selor Health Officers who have experience in } \\
\text { health cases to provide the understanding and explain to the } \\
\text { public about health cases that can encourage people to } \\
\text { transform or change a view on health. }\end{array}$ \\
\hline
\end{tabular}

\begin{tabular}{lll}
$\begin{array}{l}\text { Meaning and Action } \\
\text { Loops }\end{array}$ & $\begin{array}{l}\text { How meaning can be interpreted repeatedly to find } \\
\text { a change in action. }\end{array}$ & $\begin{array}{l}\text { Tanjung Selor Health Workers interact consistently and } \\
\text { repeatedly to create meaning and sustainable actions to be } \\
\text { able to impart health information to the public. }\end{array}$ \\
\hline Coordination & $\begin{array}{l}\text { The process of organizing the interwoven } \\
\text { Meanings and Actions to harmonize coordinated } \\
\text { actions between individuals }\end{array}$ & $\begin{array}{l}\text { approaching and maintaining coordination with all levels of } \\
\text { society and related sectors so that the interaction process can } \\
\text { be maintained. }\end{array}$ \\
\hline Story & $\begin{array}{ll}\text { How events can improve coordination of actions } \\
\text { and help understand the situation. }\end{array}$ & $\begin{array}{l}\text { In community interactions with Health Workers, they tell } \\
\text { about the negative impacts caused in pre-existing health } \\
\text { cases so that the community understands this. }\end{array}$ \\
& $\begin{array}{l}\text { Health workers try to tell the GERMAS program through } \\
\text { mobile broadcast services so that they can change their } \\
\text { views on health cases so that through interactions that are } \\
\text { built, the community can also have openness in their health } \\
\text { history. }\end{array}$
\end{tabular}

\section{Conclusion}

Human life in daily communication will build meaning from the social reality created by each individual. In general, CMM theory refers to how individuals set rules to create and interpret the meaning and how these rules are interwoven in a conversation where meaning is always coordinated. CMM theory focuses on the relationship between the individual and society. The results of this study indicate that the role of health workers in disseminating GERMAS during the Covid-19 pandemic according to the coordinated management of meaning theory by conducting social interactions with the community in mobile broadcasting activities during the distribution deworming drugs to children and Covid-19 vaccinations. This theory proves that this research has a reasonable interpretation in an approach by Health Workers when carrying out mobile broadcasting activities during the COVID-19 pandemic. This is evidenced by the efforts of health workers in attracting the community's attention by using various unique ways, for example, by providing package packages. Health services to the public when conducting outreach activities and using GERMAS music in mobile broadcasting activities to attract public attention.

Community response to the role of health workers in disseminating GERMAS during the COVID-19 pandemic according to the coordinated management of meaning theory, namely the community's enthusiasm in carrying out social interactions with health workers regarding the distribution of deworming drugs to children and carrying out Covid-19 vaccination services. In response to 
the information received by the public, they are also more interested when health workers offer gifts in the form of a GERMAS health package. This can attract people's attention to come and interact during mobile broadcast activities. Even though the community considers the mobile broadcast service ineffective, this activity can make it easier for the district to directly meet with health workers to obtain information about the GERMAS program, especially the distribution of deworming drugs to children and vaccination activities quickly and accurately.

\section{References}

Centerforhealthsecurity.org. (2019). Explore Our COVID-19 Resources and Updates. Retrieved in 2019, from https://www.centerforhealthsecurity.org/news/center-news/2019/.

Damsar, D. (2012). Pengantar Sosiologi Pendidikan. Jakarta, Kencana.

Endrawati, E. (2015). Endrawati, E. (2015). Penerapan Komunikasi Kesehatan Untuk Pencegahan Penyakit Leptospirosis Pada Masyarakat Desa Sumberagung, Kecamatan Moyudan, Sleman, Yogyakarta. Jurnal Komunikasi, 7(1), 1-25. Retrieved from https://journal.untar.ac.id/index.php/komunikasi/article/view/4

Liliweri, A. (2011). Komunikasi Serba Ada Serba Makna. Kencana.

Little, J., \& Foss, K. (2009). Teori Komunikasi, Edisi 9. Jakarta: Salemba Humanika.

Little, J., Foss, K., Stephen, W., \& Oetzel, J. G. (2017). Theories of Human Communication: 11th Edition. Long Grove: Waveland Press Inc.

Morissan. (2013). Teori Komunikasi Individu Hingga Massa. Jakarta: Prenadamedia Group.

Nationalgeographic.grid.id. (2020). Dampak Pandemi COVID-19: Hantam Sistem Layanan Kesehatan dalam 4 Gelombang. Retrieved in October, 12, 2020, from web National Geographic: https://nationalgeographic.grid.id/read/132255604/dampakpandemi-Covid-19-hantam-sistem-layanan-kesehatan-dalam-4-gelombang?page=all

Notoatmodjo, S. (2005). Metodologi Penelitian Kesehatan (Edisi Revisi).

Patton, M. Q. (2015). Qualitative Evaluation and Research Methods: Integrating Theory and Practice. Sage Publications.

Pearce, W. B. (2008). Making Social Worlds: A Communication Perspective. John Wiley \& Sons.

Putri, K. A., \& Sawitri, D. R. (2018). Hubungan Antara Efektivitas Komunikasi Interpersonal Siswa Dan Guru Dengan Prokrastinasi Akademik Pada Siswa Sma Negeri "X". Jurnal Empati, 7(1), 165-174. Retrieved from https://ejournal3.undip.ac.id/index.php/empati/article/view/20174

Rosenbaum, P. R. (2002). Design of Observational Studies (Vol. 2). New York: Springer. doi:10.1007/978-1-4757-3692-2.

Seitel, F. P. (2016). The Practice of Public Relations. Jakarta, Indonesia: PT. Gelora Aksara Pratama.

West, R., \& Turner, H. L. (2009). Pengantar Teori Komunikasi: Analisis dan Aplikasi. Pengantar Teori Komunikasi: Analisis dan Aplikasi, 77.

Yin, R. K. (2013). Case Study Research: Design and Methods (Vol. 5). Sage.

Publisher's Note: SSBFNET stays neutral with regard to jurisdictional claims in published maps and institutional affiliations.

\section{(a) (1)}

(C) 2021 by the authors. Licensee SSBFNET, Istanbul, Turkey. This article is an open access article distributed under the terms and conditions of the Creative Commons Attribution (CC BY) license (http://creativecommons.org/licenses/by/4.0/).

International Journal of Research in Business and Social Science (2147-4478) by SSBFNET is licensed under a Creative Commons Attribution 4.0 International License.

\section{Appendix}

Appendix 1: Tanjung Selor Public Health Rate

\begin{tabular}{llll}
\hline No & Disease Type & Before Covid-19 & After Covid-19 \\
\hline $\mathbf{1}$ & Hematocrit & 1,844 & 679 \\
\hline $\mathbf{2}$ & Coronary heart disease & 32 & 8 \\
\hline $\mathbf{3}$ & Heart failure & 450 & 100 \\
\hline $\mathbf{4}$ & Diabetes mellitus & 868 & 201 \\
\hline $\mathbf{5}$ & Stroke & 60 & 11 \\
\hline $\mathbf{6}$ & Asthma & 207 & 62 \\
\hline $\mathbf{7}$ & Chronic Obstructive Pulmonary & 95 & 18 \\
\hline & Total & $\mathbf{3 , 5 5 6}$ & $\mathbf{1 , 0 7 9}$ \\
\hline
\end{tabular}

Source : Tanjung Selor Public Health Center data, 2020. 